\title{
Wealth Creation and Destruction from Brooke Group's Tobacco Litigation Strategy
}

\author{
Sandeep Dahiya \\ Department of Finance \\ McDonough School of Business \\ Georgetown University \\ $37^{\text {th }}$ and $\mathrm{O}$ Streets, NW \\ Washington, DC 20057 \\ Phone: (202) 687-3832 \\ Fax: (202) 687-4031 \\ Email: sd@msb.edu \\ David Yermack \\ Department of Finance \\ Stern School of Business, New York University \\ 44 West 4th Street, Suite 9-160 \\ New York, NY 10012 \\ Phone: (212) 998-0357 \\ Fax: (212) 995-4220 \\ E-mail: dyermack@stern.nyu.edu
}

December 1999

\begin{abstract}
We examine value creation and destruction in the tobacco industry due to the radical litigation strategy pursued by Brooke Group and its CEO, Bennett LeBow. Brooke Group has a tiny market share, low margins, high leverage, and a high concentration of management ownership. Beginning in 1996 the firm reached settlements in lawsuits brought against all cigarette companies by class action plaintiffs and U.S. state governments. Brooke Group's actions, which included promises to cooperate in litigation against its rivals, spurred other companies to reach settlements on less favorable terms. The settlements eventually led to massive wealth destruction within the tobacco industry but impressive returns for shareholders of Brooke Group.
\end{abstract}




\section{Wealth Creation and Destruction from Brooke Group's Tobacco Litigation Strategy}

\section{Introduction}

On March 13, 1996, Bennett LeBow, Chairman, CEO and controlling shareholder of Brooke Group Ltd., announced that his firm had agreed to settle Castano v. American Tobacco Co., 84 F. 3d 734 (1996), a class action lawsuit filed by cigarette smokers against the major U.S. tobacco companies. Within two days LeBow also reached settlements with five U.S. states that had sued cigarette manufacturers to recover the cost of tobacco-related Medicaid and Medicare expenses. A more comprehensive settlement between LeBow's company and 22 plaintiff states followed in March 1997. By breaking ranks with industry counterparts who had steadfastly maintained no responsibility for health hazards of smoking, LeBow set the stage for the larger settlement that the industry reached with 46 state governments in November 1998.

Brooke Group owns a controlling interest in Liggett, the fifth largest cigarette maker in the U.S. Liggett has a tiny market share, and Brooke Group's capital structure and ownership pattern differ significantly from those of other tobacco companies. Brooke Group's settlements of smoking lawsuits had a dramatic impact on share prices throughout the industry: over the two days following the initial March 1996 announcements, more than $\$ 7$ billion disappeared from the market capitalization of other tobacco companies, while Brooke Group's equity value rose by $\$ 30$ 
million, a net-of-market abnormal gain of nearly 20 percent. Similar patterns of returns occurred over the subsequent three years as the tobacco industry's litigation strategy evolved from defiance toward conciliation. Brooke Group shareholders earned returns that were modest in dollar value but enormous in percentage terms, as LeBow repeatedly obtained lenient settlements for his company while agreeing to assist plaintiffs and regulators in their efforts against his far larger rivals. In contrast, other tobacco investors lost billions as the legal environment's deterioration -abetted by LeBow's cooperation with outsiders -- motivated companies to settle litigation on terms they had once viewed as unimaginable.

This paper follows LeBow's management of Liggett beginning in 1986, when he purchased its tobacco operations from Grand Metropolitan Plc. in a highly leveraged transaction. In many ways Liggett and LeBow epitomized the move towards debt financing and concentrated ownership in corporate America during the 1980s. In a series of mostly unsuccessful investments, LeBow pursued a strategy of buying financially troubled companies with junk bond financing, raising their value through asset sales and operational improvements, and recouping his investment by selling a minority stake in an initial public offering. This approach was designed to give LeBow handsome profits on his initial investment while allowing him to retain residual control of the firm. His performance as a creator of shareholder value was at best mixed; Business Week in a 1996 profile described LeBow as a "minor-league bottom-fisher" and "thirdtier wheeler-dealer" (Lesly, 1996), and several of his investments led to bankruptcies and shareholder lawsuits. Table 1 gives a chronology of LeBow's major ventures apart from Liggett. Stock return data indicate that LeBow's Brooke Group shareholders earned handsome returns while other tobacco company stocks performed poorly amid the turmoil LeBow helped 
create. Figure I shows the value over time of a $\$ 1.00$ investment in the four public U.S. tobacco stocks on August 1, 1995, the approximate beginning of LeBow's restructuring activities; the graph extends to September 30, 1999, soon after the announcement of the U.S. government's lawsuit against the industry. For comparison purposes, the results of a $\$ 1.00$ investment in the S\&P 500 Index are also shown. A \$1.00 investment in Brooke Group would have grown in value to $\$ 4.35$ during the time studied, compared to an outcome of $\$ 2.28$ from investing in the market index. All three of the other tobacco stocks -- Philip Morris, RJR-Nabisco, ${ }^{1}$ and Loews - trailed the market during this period, yielding $\$ 1.71, \$ 1.28$, and $\$ 1.22$, respectively, from a hypothetical $\$ 1.00$ investment. Since the other firms were far larger than Brooke Group, their loss in market capitalization represented a small transfer of value to Brooke Group, and a much larger transfer to legal claimants, principally state governments.

Within the tobacco industry, LeBow's efforts to create value differed markedly from the strategies of his rivals. While other companies were preoccupied with overseas expansion and cutthroat domestic battles for market share, LeBow paid little attention to the product markets and instead focused on changing the financial structure of Liggett. His initiatives involved a series of attempts to limit legal liabilities associated with tobacco-related illnesses. Although these liabilities were hypothetical at the time that LeBow acquired Liggett, we argue that he viewed them as an enormous contingent claim against his firm's assets and a significant part of Brooke Group's capital structure. Accordingly, LeBow sought to raise the value of his equity investment by taking actions that he hoped would reduce expected damage payments by his firm.

\footnotetext{
${ }^{1}$ RJR-Nabisco spun off its R.J. Reynolds tobacco operations into a stand-alone company on June 15, 1999. Calculations of shareholder returns throughout the paper use the stock of RJR-Nabisco prior to that date, and R.J. Reynolds thereafter.
} 
Our paper contributes to the literature on how the incentive effects of debt impact corporate strategy and the value of the firm. The example of Brooke Group suggests that these effects are intensified by the presence of potential legal liabilities which can be viewed as a form of pseudo-debt. While tobacco companies have operated within a unique regulatory and political environment, our findings also have relevance for other types of firms that face large hypothetical liabilities, such as those in the handgun, chemical or nuclear power industries. The analysis also has implications for issues such as financial market and product market interaction and the costs and benefits of concentrated ownership.

Figure II provides a schematic of Brooke Group's capital structure using actual 1995 values of long-term debt (book value) and equity (market value). In addition to these traditional components of capital structure, the figure includes a third piece, the expected value of future legal liabilities. Among investors and analysts, these potential damage payments were widely viewed as a drag on firms' equity values; securities analysts often cited legal liability concerns as the reason that tobacco stocks did not trade at the same multiples as equities in comparable industries like food and agricultural products. LeBow's strategy amounted to reducing or eliminating the value of these claims, hoping to transfer the asset value shown on the left side of Figure 1 from legal claimants to equity investors.

LeBow's strategy to reduce litigation exposure evolved through three distinct phases. First, in conjunction with raider Carl Icahn, LeBow attempted to merge Liggett's tobacco operations with those of RJR-Nabisco and engineer a spinoff of RJR's non-tobacco assets, in order to isolate those assets from the reach of potential jury verdicts. Second, in the midst of his battle for RJR, LeBow settled the Castano and state lawsuits, hoping that RJR shareholders 
would view the settlement terms favorably and therefore support his bid for control. However, RJR shareholders repudiated this strategy and backed management in an April 1996 proxy vote. Finally, faced with objections within the industry over his attempts to reduce litigation exposure, LeBow turned against his competitors, settled lawsuits on his own, and began cooperating with government regulatory and litigation efforts.

LeBow's strategic perspective differed wildly from the publicly announced beliefs of other companies in the industry, who disingenuously insisted they faced zero potential legal liability and buttressed this position with aggressive publicity capaigns, litigation defense, and contributions to public officials. ${ }^{2}$ For this strategy to succeed, the industry required unanimous participation from its members, given that all companies had similar access to potentially damaging legal materials. However, the incentives for LeBow to participate in this scheme were not clear-cut. LeBow realized only a tiny share of the benefits from the industry's coordinated defiance, given his firm's negligible market share, and its high leverage meant that any costs of deviating from the group strategy would have fallen largely on LeBow's debtholders (and his rivals). If regulators or litigators secured LeBow's cooperation, they could extract enormous economic rents from other, larger tobacco companies and potentially share this value with LeBow, leaving him with far more than he was earning from the operation of Liggett. We are surprised that other tobacco firms did not pay greater heed to the possibility that LeBow would adopt this viewpoint and break ranks.

Given Brooke Group's capital structure, LeBow's maverick actions seem to fit squarely with Jensen and Meckling's (1976) predictions about the owner-manager of an extremely levered

\footnotetext{
${ }^{2}$ France (1998) describes how tobacco firms' counsel worked together over a period of years to coordinate the industry's litigation strategy. Seib (1998) provides an account of how campaign contributions led to a "special relationship" between the tobacco industry and the Republican party.
} 
firm, who should be expected to pursue risky strategies with high possible payoffs but low probabilities of success. These risk-shifting incentives arising from the conflicts of interest between equity and risky debt have been discussed extensively in the finance literature (see Green (1984) and John (1987)). Additionally, our paper highlights the less documented conflicts of interest between security holders (debt, equity) and other claimants against the firm (employees, suppliers, consumers, and society at large). This issue is addressed by Shleifer and Summers (1988), who argue that the financial gains from takeovers may partly represent wealth transfers from employees and communities. In the tobacco industry, the struggle over assets between equity holders and litigation claimants has resembled similar conflicts in such industries as asbestos (Johns Manville), birth control devices (A.H. Robins), and silicone breast implants (Dow Corning).

In addition to its implications for the incentive properties of debt, our paper has relevance for legal theories of plea bargaining in which the first mover obtains more lenient treatment by agreeing to cooperate with authorities. Kobayashi (1992) provides a model in which a prosecutor uses plea bargaining as a device to "buy" information from malfeasors. Bebchuk (1984) and Reinganum (1988) are related works.

The paper is organized as follows. Section 2 describes the background of Liggett and LeBow and the financial strategy LeBow used to acquire Liggett through his Brooke Group investment vehicle. Section 3 provides background information on tobacco litigation. Section 4 examines the creation and destruction of value at Brooke Group and other firms due to strategic actions taken by LeBow. Section 5 concludes. 


\section{History of Liggett}

Started in 1822 as a snuff shop, Liggett and Myers Tobacco Co. (L\&M) grew into a major plug tobacco manufacturer by the late 19th century and became a part of the American Tobacco Trust assembled in 1899 by James Buchanan Duke. After the U.S. Supreme Court dissolved the Trust in 1911, L\&M emerged as one of the four largest U.S. tobacco companies, along with R.J. Reynolds, Lorillard, and a new American Tobacco Company. For L\&M, the next half-century was one of decline as the company dropped in tobacco sales rank. However, the company became highly diversified with interests in liquor, pet food, sports apparel, and other lines of business. In 1980 L\&M was acquired in a hostile takeover by Grand Metropolitan Plc., the large British manufacturer of food and consumer products, for $\$ 590$ million.

LeBow bought L\&M's tobacco operations from Grand Met in 1986 for \$137 million, of which $\$ 14$ million was put up by him and a group of investors and the rest was raised through junk bond financing. At the time of LeBow's acquisition, L\&M (by then renamed Liggett Group) generated healthy cash flow, and LeBow received \$30 million in dividends during his first year of ownership. He took Liggett public in October 1987, less than two weeks before the stock market crash, selling 17 percent of his equity for $\$ 48$ million. This transaction put the value of LeBow's remaining 83 percent stake at $\$ 240$ million, which combined with the $\$ 30$ million in dividends provided a stunning one-year return on his \$14 million investment (Lowenstein, 1989).

In 1990 LeBow merged his privately held Brooke Partners with Liggett and renamed the merged company Brooke Group. This restructuring, which encumbered Liggett's assets with \$300 million of Brooke Partners high-yield debt, had a very unfavorable effect on Liggett's share price. Shareholders sued to undo the merger but were unsuccessful. Lowenstein (1990) provides 
a lively news account of these events. LeBow then used Brooke Group as a holding corporation for equity positions in other ventures, including Western Union Corp. (later renamed New Valley Corp.) and MAI Systems, both of which were experiencing severe financial difficulties when acquired.

LeBow undertook to raise the value of Brooke Group's investment in Liggett by pursuing various merger and restructuring plans within the tobacco industry. LeBow attempted in 1988 to merge Liggett with American Brands, the third largest cigarette manufacturer at that time, but his informal overtures were rejected by American Brands' board. Later he joined forces with Carl Icahn to launch a series of proxy fights aimed at forcing RJR-Nabisco to spin off its non-tobacco operations and merge them with Liggett. RJR management resisted these attempts, which LeBow abandoned soon after losing a shareholder vote in April 1996. Near the end of his efforts to merge with RJR, LeBow entered into the first of his series of settlements of tobacco-related lawsuits. While LeBow's initial settlement efforts appeared to represent tactical moves within his battle for RJR, their impact on the tobacco industry continued long after the RJR fight ended.

\section{Tobacco litigation in the U.S.}

Three waves of tobacco litigation have taken place in the United States. ${ }^{3}$ Both the first wave (1950s to early 1960s) and the second (1980s to early 1990s) consisted entirely of individual personal injury cases. The current, third wave of litigation has been marked by a much larger role of the federal and state governments. Significant differences in the regulatory and legal environments faced by the tobacco industry during each of these phases affected patterns and

\footnotetext{
${ }^{3}$ Our discussion of the history of tobacco litigation draws heavily on Rabin (1992).
} 
outcomes of litigation. While the tobacco industry was famous for decades for never having lost a case, by the mid-1990s the possibility that firms would one day be held liable for large damages seemed more likely.

\subsection{The First Wave (1950s-60s)}

During the early 1950s a host of new medical studies suggested a high correlation between smoking and the incidence of lung cancer. ${ }^{4}$ These reports received wide coverage in the popular media. ${ }^{5}$ The first wave of cigarette litigation started soon after with the filing of Lowe v. R.J. Reynolds, No. 9673(C) (E.D. Mo., filed Mar. 10, 1954). More than 100 personal injury cases were filed subsequently. Most alleged that plaintiffs had suffered injuries either as a result of tobacco companies' negligent failure to warn consumers of the dangers of cigarettes, or, alternatively, because cigarette companies did not manufacture a product reasonably fit for use by consumers.

Most of these cases, including Lowe, were simply dropped by plaintiffs without formal disposition (Rabin, 1992), largely as a consequence of the legal defense strategy adopted by the tobacco industry. The industry decided to defend every claim, regardless of cost, through exhaustive discovery, inquiry into plaintiffs' personal habits and medical histories, lengthy trials involving numerous expert witnesses, and all necessary appeals. The financial resources that the industry used to underwrite this costly litigation strategy were too large to be matched by a

\footnotetext{
${ }^{4}$ Leading examples include Wynder and Graham (1950) and Doll and Hill (1950). Earlier works had linked smoking to diseases, but these lacked the rigid scientific protocol required to establish causation. Whelan (1984) mentions many of these early studies.

${ }^{5}$ Examples included The New York Times (May 27, 1950), Reader's Digest (December 1952, July 1954), Life (December 21, 1953), and "See It Now," a popular CBS television program, May 31 and June 7, 1955 broadcasts.
} 
typical small law firm or "lone wolf" personal injury lawyer who represented plaintiffs, generally on a contingency-fee basis that required attorneys to bear the entire costs of litigation. ${ }^{6}$

\subsection{The Second Wave (1980s-Early 1990s)}

On January 11, 1964, the U.S. Surgeon General's Advisory Committee on Smoking and Health released its report that examined data about smoking. The essence of its findings was contained in a summary conclusion:

" Cigarette smoking is a health hazard of sufficient importance in the United States to warrant appropriate remedial action." [Emphasis in original] (U.S. Surgeon General, p. $33)$.

Over the next two decades, the American public experienced a great attitudinal shift towards smoking as its appeal faded due to health concerns. Figure III shows that after publication of the Surgeon General's report in 1964, per capita consumption of cigarettes in the United States began a sustained, pronounced decline. Much federal legislation and rulemaking was enacted to restrict the tobacco industry, including such provisions as bans on advertising in broadcast media and prohibitions against smoking on commercial airline flights. Table 2 presents a chronology of U.S. regulatory milestones.

By the early 1980s, the evolution of product liability tort law had made suing the tobacco industry more credible (Rabin 1992). Personal injury lawyers had scored impressive victories in asbestos, Dalkon Shield, and Agent Orange "toxic tort" cases. These verdicts occurred partly because of a greater willingness by state courts to impose strict liability on firms that were found

\footnotetext{
${ }^{6}$ In the words of an R. J. Reynolds lawyer, "The aggressive posture we have taken regarding deposition and discovery in general continues to make these cases extremely burdensome and expensive for the plaintiffs' lawyers. . . To paraphrase General Patton, the way we won the cases is not by spending all of Reynolds' money, but by making that other son-of-bitch spend all of his." (Hilts, 1996, p. 197).
} 
to manufacture an "intrinsically dangerous" product, and lawyers hoped to convince courts to apply this standard against cigarette manufacturers. The most celebrated of the second wave cases, Cipollone v. Liggett Group, Inc., 593 F. Supp. 1146 (D. N.J. 1984), was handled by a team of attorneys who had worked on asbestos cases.

Cigarette manufacturers mounted successful defenses against Cipollone and similar suits based on the principle of assumption of risk. Ironically, these defenses generally relied on the Federal Cigarette Labeling and Advertising Act, Pub. L. No. 89-92 Stat. 282 (1965), which had been passed by Congress in 1965. Seen at the time of passage as a setback for the industry, the act required all cigarette packages and advertisements to contain health warnings. Defense lawyers argued that the act, passed by the federal government, preempted damage actions under state law challenging either the adequacy of the warnings on cigarette packages or the propriety of cigarette companies' advertising and promotion. ${ }^{7}$ This line of defense was upheld by the Third Circuit U.S. Court of Appeals in April 1986, and the U.S. Supreme Court refused to review this ruling in December $1987 .{ }^{8}$ However, this issue was again considered by the U.S. Supreme Court in 1992, and this time the Court opened the doors for plaintiffs to sue cigarette companies if evidence existed of concealment or misrepresentation of relevant information. ${ }^{9}$ This ruling had extremely important implications for future litigation, since it implied that if the industry knew of

\footnotetext{
7 The relevant section of the act states, "No requirement or prohibition based on smoking and health shall be imposed under the state laws with respect to the advertising or promotion of any cigarettes the packages of which are labeled in conformity with the provisions of this chapter."

${ }^{8}$ Cipollone vs. Liggett Group, Inc., 789 F.2d 181 (3rd Cir. 1986), cert. denied, 479 U.S. 1043 (1987). Despite these setbacks a jury awarded $\$ 400,000$ to the plaintiffs of the Cipollone case, the first time that the tobacco industry had actually lost a case. However, the award was overturned on appeal, and the plaintiffs dropped the suit in 1991 after eight years of litigation due to lack of resources. Kluger (1996) provides a detailed description of the progress and termination of this suit.

${ }^{9}$ Cipollone vs. Liggett Group, Inc., 505 U.S. 504 (1992).
} 
dangers of smoking that it had not revealed, it could be liable for damages.

\subsection{The Third Wave (1994-Present)}

In 1994 a series of events precipitated a new wave of litigation that has so far resulted in settlements requiring the industry to pay out several hundred billion dollars in damages over the coming years. In April 1994, the CEOs of U.S. tobacco firms testified before a House of Representatives subcommittee on Health and the Environment. In these nationally televised hearings, CEOs swore under oath that they did not believe nicotine to be addictive. This testimony was contradicted by the release of internal research documents of Brown \& Williamson Co. $(B \& W)$ later that year which revealed that $B \& W$ was aware of the addictive nature of nicotine. ${ }^{10}$ In March 1995, the head of the U.S. Food and Drug Administration, citing statistics indicating that most smokers acquire the habit before 18 , began a high-profile deliberation over whether to classify nicotine and cigarettes as drugs that cause a "pediatric disease." In May President Clinton threw his support behind the FDA's parallel initiatives to impose marketing restrictions upon the industry.

Plaintiffs' lawyers joined together to file new class action cases, the most significant of which was Castano. More importantly, U.S. state governments also began litigation against the tobacco companies. Starting with a suit filed by Mississippi on May 24, 1994, states sought to recover costs they had borne for treating tobacco-related illnesses among the welfare recipients of

\footnotetext{
${ }^{10}$ These documents, now known as "The Cigarette Papers," arrived unsolicited in a box at Professor Stanton Glantz's office at the University of California, San Francisco. Copies of the actual documents are deposited in the Archives and Special Collections Department of the Library at UCSF and are available to public. These papers have since been admitted as evidence in a number of trials. The story of how these documents were purloined by a paralegal working for Brown \& Williamson has been told in many newspaper stories. An interesting source is Hilts (1996).
} 
their populations. Mississippi was immediately joined by Florida and West Virginia. By the end of June 1997, 39 states had sued the cigarette manufacturers, taking part in the most important innovation to date in tobacco litigation. The strategy was eventually emulated by a variety of other institutional and government claimants, including pension funds, foreign governments, and finally, the U.S. federal government in September 1999.

\section{LeBow's efforts to create value from Brooke Group's ownership of Liggett}

To understand LeBow's non-traditional attempts to limit the dangers of litigation to the tobacco industry, one must appreciate how differently Brooke Group was financed and performed compared to its rivals. Table 3 presents relevant financial and product market data about the four public U.S. cigarette companies in 1995. Brooke Group, with 2 percent market share and slightly more than $\$ 300$ million in annual sales, was dwarfed in size by the others. Brooke Group barely broke even in terms of its operating profits, while its rivals earned extremely attractive margins, and Brooke Group was far more heavily leveraged than the others. This combination of low profitability and high leverage implied that LeBow had little to lose if he pursued strategies that turned out to destroy value, as the wealth reduction would largely impact Brooke Group's creditors. On the other hand, LeBow owned 56.5 percent of Brooke Group's equity, an extraordinarily high ownership concentration that allowed him personally to enjoy the benefits from any wealth creation strategy. We believe LeBow's management of Liggett reflected these asymmetric incentives, as he pursued extraordinarily risky tactics that would have made far less sense in a profitable, low-levered firm with a low concentration of management ownership. 


\subsection{Attempts to gain control of RJR-Nabisco}

LeBow's first efforts to reduce the impact of legal liabilities on the value of tobacco companies occurred during his 1995-96 campaign for control of RJR-Nabisco. RJR, the wellknown tobacco and food company whose 1989 leveraged buyout was the theme of the bestseller Barbarians at the Gate, had seen its stock price languish after an initial public offering in 1991. Analysts widely attributed the stock's weakness to the possibility that RJR's food assets might someday be liquidated to satisfy the damage claims of tobacco litigants. LeBow sought to increase the value of RJR by proposing a spinoff of the food assets as a way of removing the hypothetical litigation encumbrance. He also proposed to merge RJR's tobacco operations with those of his own company, Liggett.

Table 4 and Figure IV show the abnormal wealth increases for both Brooke Group and RJR-Nabisco during LeBow's 1995-96 restructuring efforts, which were steadfastly opposed by RJR management. We calculate abnormal stock returns as the difference between each company's stock return and the return on the S\&P 500 Index. ${ }^{11}$ Abnormal changes in market capitalization equal the product of each firm's market cap and the abnormal stock return. All returns are presented on a cumulative three-day basis, lasting from the day before to the day after each event.

In August 1995, LeBow received regulatory clearance from the U.S. Federal Trade Commission to buy as much as 15 percent of RJR-Nabisco stock. RJR also disclosed that it had previously rejected a proposal by LeBow to combine its tobacco operations with Brooke Group's

\footnotetext{
${ }^{10}$ We were unable to implement the more standard market model approach to calculating abnormal returns because of the atypical behavior of Brooke Group's stock up to 1995. The stock was thinly traded and extremely volatile, and we obtained unusual and unstable estimates of its â from historical regressions. T-statistics for our abnormal return calculations are based on the standard deviation of each stock's daily returns over the 120 trading days prior to August 1 , 1995.
} 
Liggett unit. Over the next two months investor Carl Icahn began a similar campaign to acquire shares in RJR and effect a spinoff of its food operations. Icahn and LeBow joined forces and together acquired just under 5 percent of RJR's stock. In October they announced plans for a proxy fight in support of a Nabisco spinoff. As shown by Table 4 and Figure IV, these initiatives increased the market cap of RJR by more than a billion dollars and fueled an enormous percentage rise in Brooke Group's stock as well.

LeBow and Icahn's non-binding spinoff proposal was narrowly passed by a special meeting of shareholders, who gave it 50.4 percent support in a February 1996 vote. RJR management ignored these results and continued to oppose a spinoff, so LeBow and Icahn began a second proxy fight to take control of RJR's board at the April annual meeting.

The battle took a dramatic turn on March 13, 1996, when Brooke Group announced the settlement of the Castano class action lawsuit and its impending settlement of suits by the five states that had filed Medicaid and Medicare lawsuits against the tobacco industry. ${ }^{12}$ Brooke Group agreed to pay up to 5 percent of its Liggett unit's pre-tax profit, up to a maximum of $\$ 50$ million annually, to the Castano settlement fund for each of the next 25 years. Brooke Group also agreed to submit Liggett's products to regulation by the U.S. Food and Drug Administration and to cease marketing cigarettes to minors. ${ }^{13}$ One crucial element of the settlement was that its terms would apply to any company with which Liggett merged in future, unless the mergee had

\footnotetext{
12 The five states were Mississippi, Florida, Louisiana, Massachusetts, and West Virginia. The significance of LeBow's actions was reflected, for example, in The Wall Street Journal's characterization of the settlement as a "shocking capitulation at a time when other tobacco firms were still vowing never to give in." Freedman and Hwang (1997).

13 The marketing restrictions involved refraining from the use of cartoon characters in cigarette advertising, eliminating any coupon, value-added benefit or service appealing to children, and not advertising within 1,000 feet of schools and playgrounds.
} 
more than 30 percent of the U.S. cigarette market. This feature was clearly aimed at the possible merger of Liggett and RJR, since the firms' combined market share would have been slightly less than 30 percent (RJR-Nabisco, 1996). Brooke Group also retained the right to back out of the settlement if any other tobacco company won a addiction-based class-action suit or managed to overturn the class action's certification. The settlement with the states was announced on March 15, 1996, and contained all the regulatory conditions included in the Castano settlement. Additionally, the five states would share 2.5 percent of Liggett's pretax profits over the next 25 years. Other states joining the settlement would share another 5 percent of the pretax profits, though total payments would be capped at $\$ 30$ million a year. In addition the company agreed to pay $\$ 135$ million up front into a fund to compensate the five plaintiff states and another $\$ 25$ million to other states that decided to join the settlement, with these payments subject to affiliation between RJR and Liggett. Finally, in a stunning breach of industry solidarity, Brooke Group promised to cooperate with states' attorneys general in their lawsuits and investigations against other cigarette companies.

Figure $\mathrm{V}$ shows that investors interpreted the settlement as a favorable event for Brooke Group and an adverse one for other tobacco companies, including RJR-Nabisco. Brooke Group stock shot up nearly 20 percent net-of-market on the announcement date while the stocks of other companies fell. All the tobacco stocks fell together over the next six days as the implications of Brooke Group's settlement became more clear. However, Figure V clearly shows that once valuations stabilized, Brooke Group had risen about 10 percent net-of-market while other companies had fallen by about the same percentage; the events can therefore be interpreted as a 
transfer of value to Brooke Group from its rivals. ${ }^{14}$ LeBow at the time appeared to have cut a more lenient deal for his company than expected by investors, in part by agreeing to assist in enforcement actions against the other companies.

LeBow had clearly negotiated settlement terms in anticipation of bootstrapping them onto the much larger RJR, and a merger seemed all but certain if LeBow and Icahn could win their proxy fight for control of RJR's board. However, LeBow's settlement tactics did not appeal to RJR shareholders, management, or tobacco analysts, all of whom excoriated him for repudiating the industry's litigation strategy. Support evaporated for LeBow and Icahn's proxy campaign; the failure of RJR's stock to rise in line with Brooke Group's after the settlement announcement suggests that investors had not expected RJR to embrace LeBow's radical strategy. On April 17 LeBow conceded defeat in the proxy fight and effectively ended his involvement with RJR. ${ }^{15}$ Figure IV and Table 4 indicate that RJR's stock gave up virtually all of the net-of-market gains it had achieved during LeBow's and Icahn's involvement. Though Brooke Group's stock also fell as the RJR merger initiative collapsed, it remained marginally (though not significantly) higher on a net-of-market basis than it had been the previous August, perhaps because investors saw value in LeBow's litigation strategy.

\subsection{Efforts to reach a comprehensive legal settlement}

A resolution of legal claims could have benefitted the industry if it had less onerous

\footnotetext{
${ }^{14}$ Cumulative abnormal stock returns are significantly negative for Philip Morris, Loews, and RJR-Nabisco throughout the event period, and significantly positive for Brooke Group only for the first two days.

${ }^{15}$ Seven months later LeBow announced plans for another attempt to gain control of RJR-Nabisco in a proxy fight, but he did not pursue this effort.
} 
consequences than investors were expecting from the array of government and personal injury suits progressing through the courts. Further, any settlement or verdict may have benefitted certain companies more than others, if its terms were contingent on such variables as market share or profitability. LeBow appears to have recognized and exploited this latter possibility, as he continued to pursue his strategy of accommodation with regulatory authorities even after it undermined his plan to merge with RJR. Table 5 and Figure VI illustrate the value consequences between March 1997 and November 1998 of events that led to the $\$ 206$ billion settlement between the major tobacco companies and 46 states. Figure VI shows that Brooke Group vastly outperformed both the S\&P 500 Index and the average of its competitors during this period (Philip Morris, RJR, and Loews all behaved similarly, and their returns are shown in an equalweighted average to reduce clutter). Though Brooke Group's stock experienced dramatic swings during this settlement negotiation period, it generally rose during times that a settlement appeared likely and fell when the industry was estranged from regulatory authorities.

From the point of view of government regulators, a settlement or verdict would have created economic rents in the form of tax revenues or damage payments. Any company that facilitated such an event -- for example, by admitting liability and agreeing to provide evidence against the entire industry, as Brooke Group did -- could reasonably ask regulators to share with it the stream of benefits. ${ }^{16}$ It is unlikely that politicians or the public would have supported direct subsidies to Brooke Group from either taxpayers or other tobacco companies. Nevertheless, in settlement negotiations it proved possible to structure agreements that permitted Brooke Group

\footnotetext{
${ }^{16}$ A clear analogy exists to criminal law, in which a defendant who cooperates with prosecutors usually receives more lenient treatment than co-conspirators who are convicted as a result of his testimony. At one point during Brooke Group's series of settlements with state governments, the attorney general of Michigan remarked that "We got the least important culprit to turn state's evidence and give testimony against the really bad guys" (Broder, 1997).
} 
to capture benefits indirectly. Brooke Group was an especially logical candidate to engage in this type of tacit cooperation with authorities against the other tobacco companies, as LeBow had no historical stake in the industry's litigation strategy and little or no ongoing cash flow to protect. Indeed, virtually the entire value of Brooke Group's market capitalization after early 1996 appeared to reflect the benefits it was expected to capture from its role as a catalyst in settling litigation, since the cash flow from its ordinary operations was barely adequate to satisfy obligations to creditors.

Brooke Group on March 20, 1977, announced a settlement of suits brought by 22 states, supplementing its settlements with five states one year earlier. As part of the new agreement LeBow agreed to issue a public statement acknowledging that smoking was responsible for causing lung cancer and other health problems, and that nicotine is addictive. Brooke Group committed to pay damages of $\$ 25$ million up front and up to 25 percent of Liggett's pretax income for the next 25 years. The deal provided for a reduction in payments if any other cigarette maker subsequently settled with the plaintiff states. It also required Brooke Group to hand over all documents that could aid the plaintiffs. This posed a substantial threat to the industry, which had vigorously fought disclosure of internal tobacco research records. The full force of how damaging the such documents could be had been revealed in August 1996, when a Florida jury awarded $\$ 750,000$ in a personal injury case, the first in which the stolen internal documents of Brown \& Williamson had been admitted as evidence.

Brooke Group's settlements appeared to force the other tobacco companies to the bargaining table and created momentum for negotiations over a comprehensive settlement of liability issues facing the industry. Within two weeks of Brooke Group's initial settlement, RJR- 
Nabisco CEO Steven Goldstone had said for the first time that he would be interested in a "resolution" of legal, regulatory and social controversy surrounding cigarettes (Freedman and Hwang, 1997). On April 16, 1997, The Wall Street Journal reported ongoing settlement talks between the major companies, the states, and other parties. An agreement was announced on June 20, 1997, purporting to offer a comprehensive resolution of both government and private claims against the industry.

Under this proposed industry-wide settlement, tobacco companies agreed to pay approximately $\$ 368.5$ billion over 25 years, including an up-front payment of $\$ 10$ billion and punitive damages of $\$ 50$ billion for past wrongdoing. The tobacco companies received some protection from future liability, as class action suits would be banned. Smokers who opted out of existing class actions would be permitted to sue individually, but the total amount of awards in their suits would be limited to $\$ 5$ billion in any year. Other settlement terms included marketing and regulatory restrictions similar to those first agreed to by LeBow in 1996. A thorough analysis of the settlement and its eventual demise appears in Bulow and Klemperer (1998).

The proposed settlement required Congressional legislation for several reasons, such as the promise that tobacco companies would receive limited immunity from class action lawsuits. The involvement of the U.S. House and Senate, which had not participated in the original settlement negotiations, complicated the process greatly. President Clinton's effective use of tobacco as an issue in his 1996 re-election campaign had made the Republican Party wary of its longstanding protective attitude toward tobacco. ${ }^{17}$ Congressmen and Senators therefore began

\footnotetext{
17 The Republicans' estrangement from the industry began after an embarrassing 1996 television interview of presidential candidate Sen. Robert Dole on the Today program, during which Dole cast doubt on the dangers of smoking. Soon after, in a widely reported quote, Speaker of the House Newt Gingrich said that he would not allow President Clinton "to get to the left of me" on the tobacco issue, implying that the Republican Congress would support tobacco legislation even more
} 
rewriting the June 1997 settlement to increase its burden on the industry.

The most notable legislation was sponsored by Republican Senator John McCain, whose bill raised the tobacco companies' future damage payments from $\$ 368.5$ billion to $\$ 516$ billion and required greater marketing restrictions than envisioned in the 1997 settlement. Other Senators and Congressmen offered similar legislation, nearly all of it anti-tobacco.

While legislators attempted to rewrite the settlement in order to extract more economic value from the industry, they also attempted to bend its terms in ways that would favor Brooke Group, apparently as a reward for LeBow's role. As described by Bulow (1998), the McCain bill included a provision subjecting each cigarette pack to a tax of $\$ 1.10$, with an exemption for those companies holding less than 3 percent market share. Assuming that Liggett increased its prices by the amount of this tax while holding its market share below 3 percent, the provision amounted to a "bonanza" potentially worth $\$ 600$ million per year to Brooke Group. LeBow's personal share of this income stream could have made him a billionaire many times over (Passell, 1998). Figure VI shows that Brooke Group's stock rose steadily and dramatically between mid-1997 and early 1998 as these indirect subsidies to Liggett were discussed in Washington; when the settlement collapsed in the late spring, Brooke Group's stock then began a decline that lasted until settlement talks revived.

Faced with much harsher marketing restrictions and damage payments than they had envisioned, the major tobacco companies began to distance themselves from the settlement legislation pending before Congress and even mounted advertising campaigns against various bills. On April 8, 1998, RJR-Nabisco repudiated the June 1997 settlement, adding that it would 
challenge in court any new restrictions unilaterally imposed by Congress. Other companies soon followed RJR's lead, and by the end of April the settlement was dead.

Walking away from the June 1997 pact did not solve the industry's liability problems, however, as states and class action attorneys resumed prosecuting their suits against the tobacco manufacturers. The potential cumulative cost of these actions soon appeared overwhelming. For example, on May 8, 1998, the companies settled with the state of Minnesota for damage payments of $\$ 6.5$ billion, and on July 6 a massive class action trial began in Florida in which several hundred thousand smokers sought damages of $\$ 100$ billion. These numbers were large enough to bring the tobacco companies back into negotiations within months; the climate for a revival of negotiations also improved when the U.S. Senate tabled the harsh McCain legislation and all related tobacco bills.

Informal talks between the industry and certain states reopened in mid-summer, and negotiations intensified until a new settlement was reached on November 20, 1998. The tobacco companies agreed to pay $\$ 206$ billion over 25 years to the 46 states with pending suits against the industry (four states' suits had already been settled). In addition, the companies agreed to observe marketing restrictions and finance research to curb youth smoking. Since the agreement required no further approval by Congress or other regulators, it was signed and became effective soon afterward.

However, many features of the June 1997 settlement were absent from the November 1998 pact, and the industry remained far more exposed to legal liability than it would have if the earlier agreement had taken effect. In particular, the industry continued to face class action suits and suits by individual smokers with no limit to potential damages. The federal government was 
also free to pursue the industry for reimbursement of health care expenditures, which it did in a lawsuit filed in September 1999. An array of foreign governments, labor unions, HMOs, and other organizations also were making use of this litigation strategy (Meier, 1988).

\subsection{LeBow's payoff}

To conclude the November 1998 settlement, the parties needed to entice Brooke Group to abandon the legal rights that it had secured in its March 1996 and March 1997 settlements with various state governments. Because of those agreements, Brooke Group did not have to obey marketing restrictions as stringent as those imposed on its rivals in the November 1998 pact, and Brooke would pay lower per-pack damages, effectively allowing it to out-market and under-price its rivals. Further, Brooke Group could potentially merge with another company and acquire up to 30 percent market share while continuing to operate under these more favorable terms. State attorneys general refused to proceed with an industry-wide settlement until the possibility could be eliminated of a renegade Brooke Group undermining the pact.

A $\$ 300$ million side payment from Philip Morris became the price of LeBow's agreeing to abide by the November 1998 settlement. The entire transaction was characterized as the sale to Philip Morris of three of Brooke Group's brands -- L\&M, Chesterfield, and Lark. Together those brands had 0.18 percent market share and $\$ 60$ million annual sales, about 15 percent of Liggett's annual volume, and their cash flow did not begun to justify the enormous price paid by Philip Morris. Essentially, LeBow had monetized the attractive settlement terms he had negotiated in 1996 and 1997. Wall Street tobacco analysts characterized the transaction variously as "the deal of the century," "amazing," and "LeBow beating the industry at its own game" (Schwartz, 1998; 
Obermayer, 1998). In addition, the new settlement allowed Liggett to avoid the estimated 40 cents per pack damage payments imposed on the other companies, so long as Brooke Group's market share remained below 1.67 percent (Edwards, 1998); this cost advantage represented a potential \$100 million in incremental annual cash flow (Obermayer, 1998).

Brooke Group's stock price rose from $\$ 9$ on November 17 to $\$ 19 \mathrm{c}$ on November 25 as the settlement terms and the Philip Morris transaction came to light, and the stock continued to rise to $\$ 24 \mathrm{~d}$ by December 31. This huge increase in the company's equity value appeared to validate LeBow's controversial litigation strategy.

\subsection{Parallel efforts by LeBow to resolve personal injury litigation}

LeBow's litigation strategy all but eliminated Brooke Group's exposure to damages from health care reimbursement actions brought against the tobacco companies by the 50 U.S. state governments. While LeBow was implementing this strategy between 1996 and 1998, he attempted to achieve a similar low-cost resolution of claims by individual smokers, whether brought as individual or class action lawsuits.

Brooke Group in 1998 reached a preliminary settlement of a class action lawsuit filed in the Alabama state courts. The agreement, in the case Fletcher v. Liggett Group, Inc., No. CV97913 (AL Cir. Ct., Mobile Cty.), purported to protect the company from further personal injury litigation anywhere in the United States. However, the settlement has been repeatedly challenged by groups protesting its leniency toward LeBow's company, and an adverse August 1999 ruling cast doubt on its future. See Tobacco Industry Litigation Reporter (1998, 1999a, 1999b), Van Voris (1998), and Schmitt (1999) 
The Fletcher settlement would absolve Liggett of all tobacco-related claims currently pending and all claims that would accrue during the next 25 years. In exchange for this immunity, Brooke Group would pay $\$ 10$ million immediately plus annual payments over the next 25 years equal to the greater of $\$ 1$ million or 9 percent of Liggett's pretax profits. The company also consented to FDA regulation of cigarettes and a host of marketing restrictions similar to those in its other settlements. From a financial standpoint, the settlement was attractive to Brooke Group partly because of Liggett's negligible operating profits; other tobacco companies would almost certainly regard the settlement's damages formula as prohibitively expensive.

At least two legal issues have emerged as roadblocks to the agreement. The first concerns whether the Alabama state courts have jurisdiction to resolve claims of smokers throughout the U.S. in the unusual "mandatory class action" format of the Fletcher case; if the settlement is eventually approved in Alabama, this issue will almost certainly serve as the basis for years of appeals in the U.S. federal courts. Second, the Fletcher settlement received court approval as a "limited fund class action" partly because of Brooke Group's precarious financial condition at the time that the suit was filed. Several groups challenging the settlement in 1999 argued that the \$300 million infusion from Philip Morris in November 1998 had significantly improved the company's balance sheet, extinguishing the rationale for a "limited fund" proceeding in which the company's assets are far smaller than its expected liabilities.

The potential value to Brooke Group and other tobacco companies of limiting immunity from personal injury suits was highlighted by two major trial verdicts against Philip Morris in early 1999. On February 10, a California jury found against the company and awarded $\$ 51.5$ million in damages to a woman who had contracted lung cancer after smoking Philip Morris's Marlboro 
brand for decades. In a similar verdict on March 30, an Oregon jury assessed damages of \$81

million against Philip Morris in a case brought by the family of a deceased lung cancer victim who had also smoked Marlboros. Though Philip Morris immediately announced plans to appeal both verdicts (and the California award was cut in half in April by a judge), its stock price and those of other tobacco companies fell sharply after both trials. ${ }^{18}$

\section{Conclusions}

The tobacco industry in the mid-1990s faced a variety of litigation claims from consumers and government authorities. Bennett LeBow, CEO of cigarette manufacturer Brooke Group, created enormous value for shareholders by adopting a litigation strategy very different from that of his industry rivals. While other tobacco companies steadfastly refused to settle lawsuits or cooperate with regulatory authorities, LeBow pursued a strategy of accommodation. By being the first firm in the industry to reach agreements with plaintiffs, LeBow's company secured lenient settlement terms in exchange for cooperating in lawsuits against others. Though LeBow's actions contributed to massive destruction of wealth within the tobacco industry, his own small firm increased in value substantially as regulators implicitly allowed Brooke Group to obtain a portion of the economic rents extracted from his competitors.

Our paper extends the literature on how debt affects managerial behavior by highlighting the connection between financial leverage and hypothetical legal liabilities. LeBow's apparent

\footnotetext{
${ }^{18}$ Interestingly, Brooke Group stock did not fall as much as other companies' in the aftermath of these verdicts. Twoday stock price changes on February 10-11 were -11.02 percent for Philip Morris, -8.71 percent for RJR-Nabisco,

-4.74 percent for Loews, and -2.80 percent for Brooke Group. On March 30-31, the stock price changes were -14.57 percent for Philip Morris, -13.61 percent for RJR, -8.15 percent for Loews, and -7.09 percent for Brooke Group (returns are statistically significant for all companies except Brooke).
} 
insight was to recognize that large contingent legal claims from tobacco lawsuits represented pseudo-debt on Brooke Group's balance sheet. Under these conditions, LeBow rationally pursued a high-risk strategy of attempting to increase equity value by reducing the value of other claims against his firm's assets. LeBow's actions seem entirely predictable to us, given his firm's tiny market share, negligible cash flow, levered capital structure (even in the absence of litigation), and high ownership concentration. Indeed, an unexplained puzzle of this story is why Philip Morris and the other tobacco companies did not recognize this possibility and buy out Liggett from LeBow years earlier, especially given his reputation as an unorthodox manager with little regard for financial convention.

Our study also illustrates opportunities for value creation for both regulators and defendant corporations during legal plea-bargaining. In our example, government authorities extended generous financial terms to a small player, and by doing so gained information that facilitated value extraction from other, larger firms. This dramatic outcome of this strategy in the case of tobacco may influence product liability litigation in other industries such as handguns. 


\section{References}

Bebchuk, Lucian, 1984. Litigation and settlement under imperfect information, RAND Journal of Economics 15, 404-413.

Broder, John M., 1997. Cigarette maker concedes smoking can cause cancer, The New York Times, March 21.

Bulow, Jeremy, 1998. A sweet deal for a tobacco executive, The Wall Street Journal, May 14.

Bulow, Jeremy and Paul Klemperer, 1998. The tobacco deal, Brookings Papers on Economic Activity, forthcoming.

Doll, Richard and A. Bradford Hill, 1950. Smoking and carcinoma of the lung: Preliminary report, British Medical Journal 2, 30 September, 739.

Edwards, Will, 1998. Brooke shares rise 59 percent, Bloomberg News, November 24.

France, Mike, 1998. Inside big tobacco's secret war room, Business Week, June 15, 134.

Freedman, Alix M. and Suein L. Hwang, 1997. Leaders of the pact: How seven individuals with diverse motives halted tobacco's wars, The Wall Street Journal, July 11.

Glantz, Stanton A., 1996. The Cigarette Papers. University of California Press, Berkeley.

Green, Richard C., 1984. Investment incentives, debt, and warrants, Journal of Financial Economics 13, 115-136.

Hilts, P. J., 1996. Smokescreen: The Truth Behind the Tobacco Industry Cover-Up. AddisonWesley, Reading, MA.

Jensen, Michael C. and William H. Meckling, 1976. Theory of the firm: Managerial behavior, agency costs, and capital structure, Journal of Financial Economics 3, 305-360.

John, Kose, 1987. Risk-shifting incentives and signalling through corporate capital structure, Journal of Finance 42, 623-641.

Kobayashi, Bruce, 1992. Deterrence with multiple defendants: An explanation for "unfair" plea bargains, RAND Journal of Economics 23, 507-517.

Kluger, Richard, 1996. Ashes to Ashes: America's Hundred-Year Cigarette War, the Public Health, and the Unabashed Triumph of Philip Morris. Knopf, New York.

Lesly, Elizabeth, 1996. RJR: Shareholder at the gate, Business Week, February 5. 
Lowenstein, Roger, 1989. Holders of LeBow's concerns get poor, Wall Street Journal, August 15.

Lowenstein, Roger, 1990. Why some holders of tobacco firm may feel burned, Wall Street Journal, November 30.

Meier, Barry, 1998. Tobacco bill's death is likely to prompt litigation landslide, New York Times, June 19.

Obermayer, Joel B., 1998. Liggett smokes tobacco rivals, Raleigh News and Observer, November 24.

Passell, Peter, 1998. Raising cigarette taxes will surely punish tobacco's victims, The New York Times, May 28.

RJR-Nabisco, 1996. Proxy statement for annual meeting of shareholders, filed April 10.

Rabin, Robert L., 1992. A sociological history of the tobacco tort litigation, Stanford Law Review 44, 853.

Reinganum, Jennifer, 1988. Plea-bargaining and prosecutorial discretion, American Economic Review 78, 713-728.

Schmitt, Richard B., 1999. Liggett acts to settle individual-smoker liability, The Wall Street Journal, March 9.

Schwartz, John, 1998. Liggett to sell 3 brands of cigarettes to Philip Morris, The Washington Post, November 21.

Seib, Gerald, 1998. How tobacco blew its affair with the GOP, Wall Street Journal, April 15.

Shleifer, Andrei, and Lawrence H. Summers, 1988. Breach of trust in hostile takeovers, in Alan Auerbach, ed., Corporate Takeovers: Causes and Consequences. University of Chicago Press, Chicago.

Tobacco Industry Litigation Reporter, 1998. Alabama judge certifies Liggett class action, approves settlement, December 28, 7.

Tobacco Industry Litigation Reporter, 1999a. TLPJ opposes Liggett settlement; fairness hearing postponed, March 12, 12.

Tobacco Industry Litigation Reporter, 1999b. AL court refuses to approve settlement of Liggett class action, August 13. 
U.S. Surgeon General, 1964. Smoking and Health: Report of the Advisory Committee to the Surgeon General. U.S. Public Health Service, Washington.

Van Voris, Bob, 1998, Liggett on verge of resolving liability, National Law Journal, December 28, A8.

Whelan, E., 1984, A Smoking Gun: How the Tobacco Industry Gets Away with Murder. Stickley, New York.

Wynder, Ernst and Evarts A. Graham, 1950. Tobacco smoking as a possible etiologic factor in bronchiogenic carcinoma: A study of 684 proved cases, Journal of the American Medical Association 143(4), 329. 


\section{Figure I}

\section{Performance of U.S. Tobacco Stocks}

August 1, 1995 - September, 1999

Value of a $\$ 1.00$ investment in the stocks of the four public U.S. tobacco manufacturers between August 1, 1995, and March 1, 1999. For comparison purposes, the dark line represents the value of a $\$ 1.00$ investment in the S\&P 500 Index. Dates are chosen to coincide with Brooke Group's active efforts to resolve private and government litigation against the tobacco industry. The stock of R.J. Reynolds is represented by RJR-Nabisco prior to its June 15, 1999 spinoff.

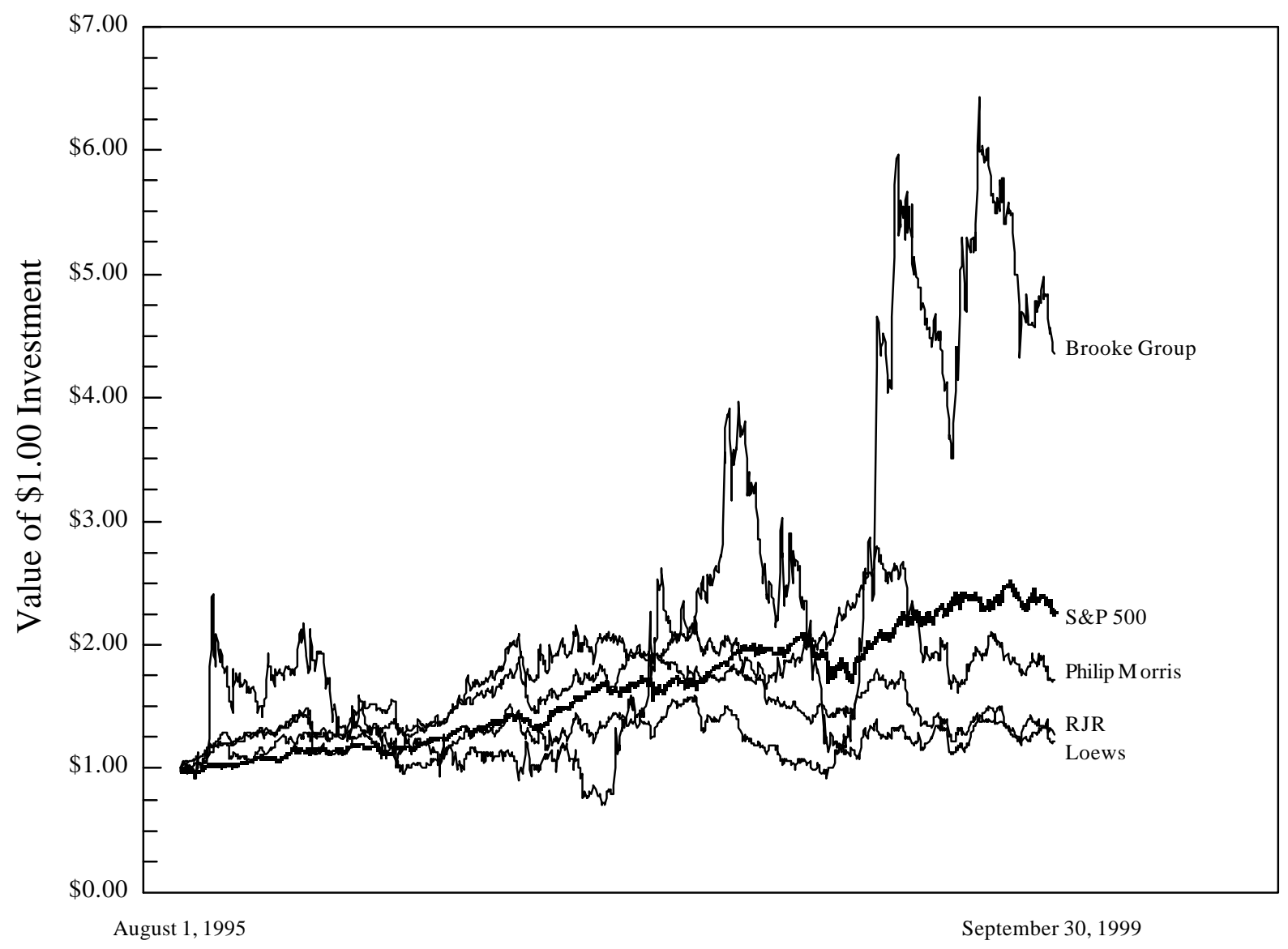


Figure II

Brooke Group's Hypothetical Asset Value and Capital Structure

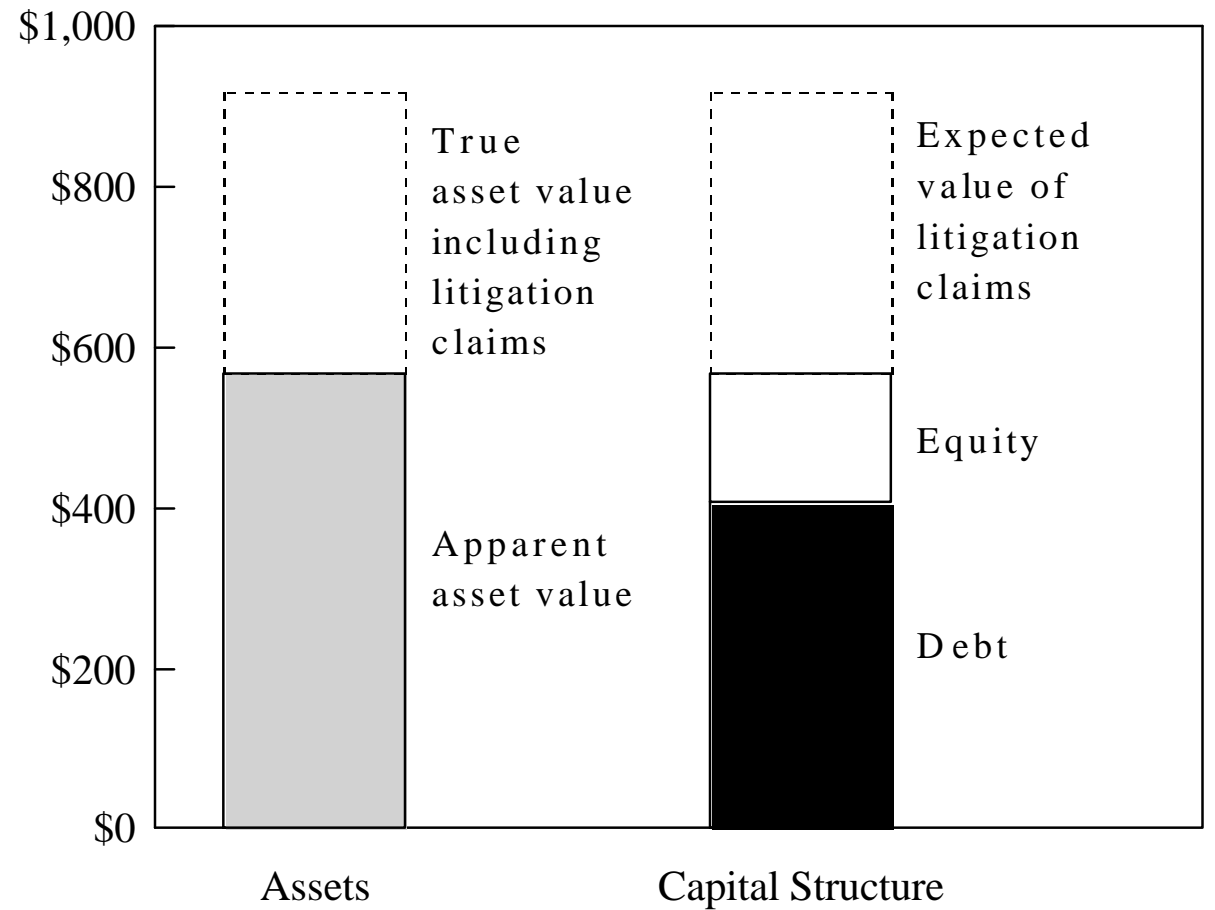




\section{Figure III}

\section{U.S. Per Capita Cigarette Consumption \\ 1958-1994}

Per capita consumption of cigarettes in the United States by year. Source:

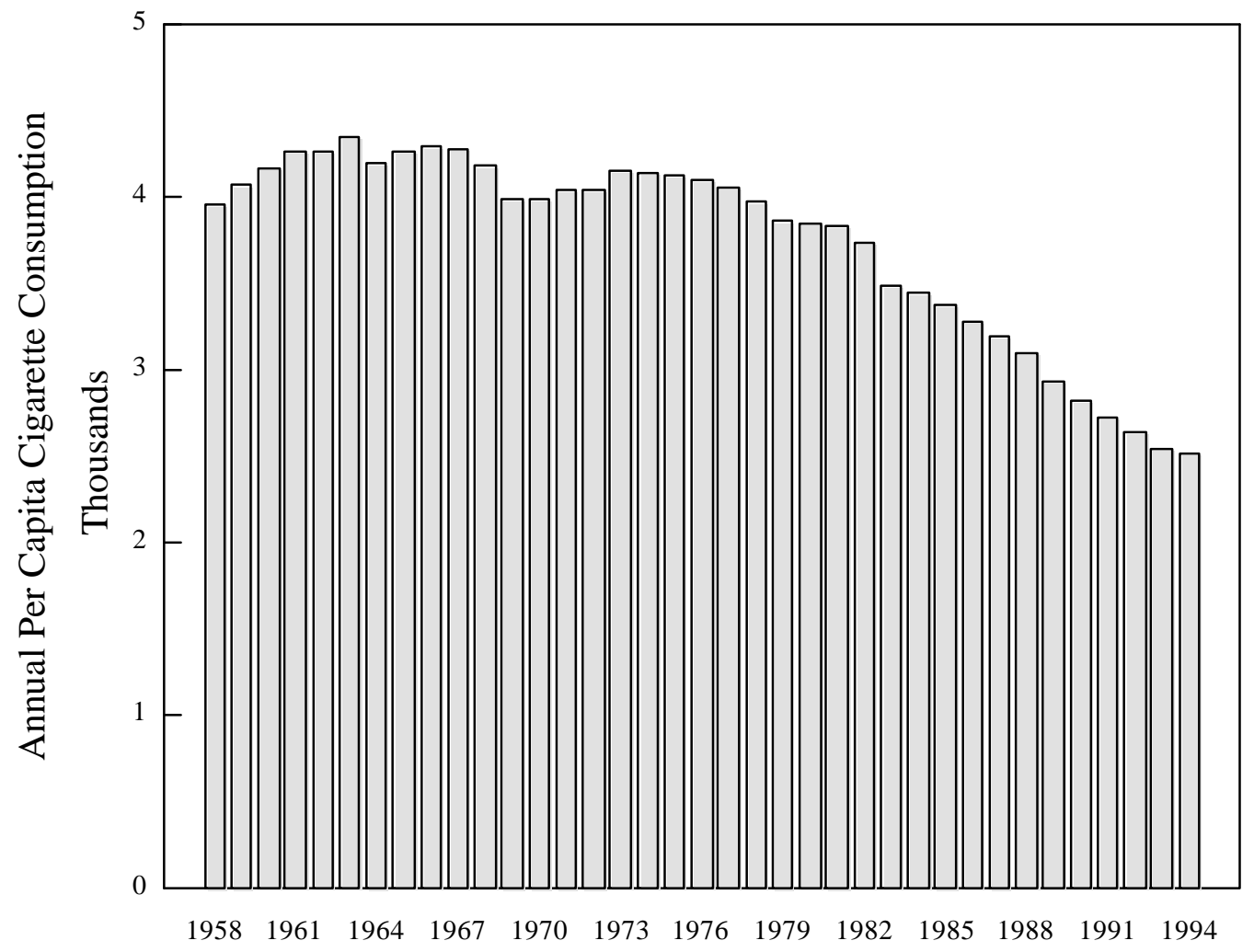




\section{Figure IV}

\section{Performance of Brooke Group and RJR-Nabisco Stock}

August 28, 1995 - April 18, 1996

Value of a $\$ 1.00$ investment in the stocks of Brooke Group and RJR-Nabisco between August 28, 1995, and April 18, 1996. For comparison purposes, the dark line represents the value of a $\$ 1.00$ investment in the S\&P 500

Index. Dates are chosen to coincide with Bennett LeBow's campaign to gain control of RJR and merge its tobacco operations with Liggett's. Stock return information was obtained from the CRSP database.

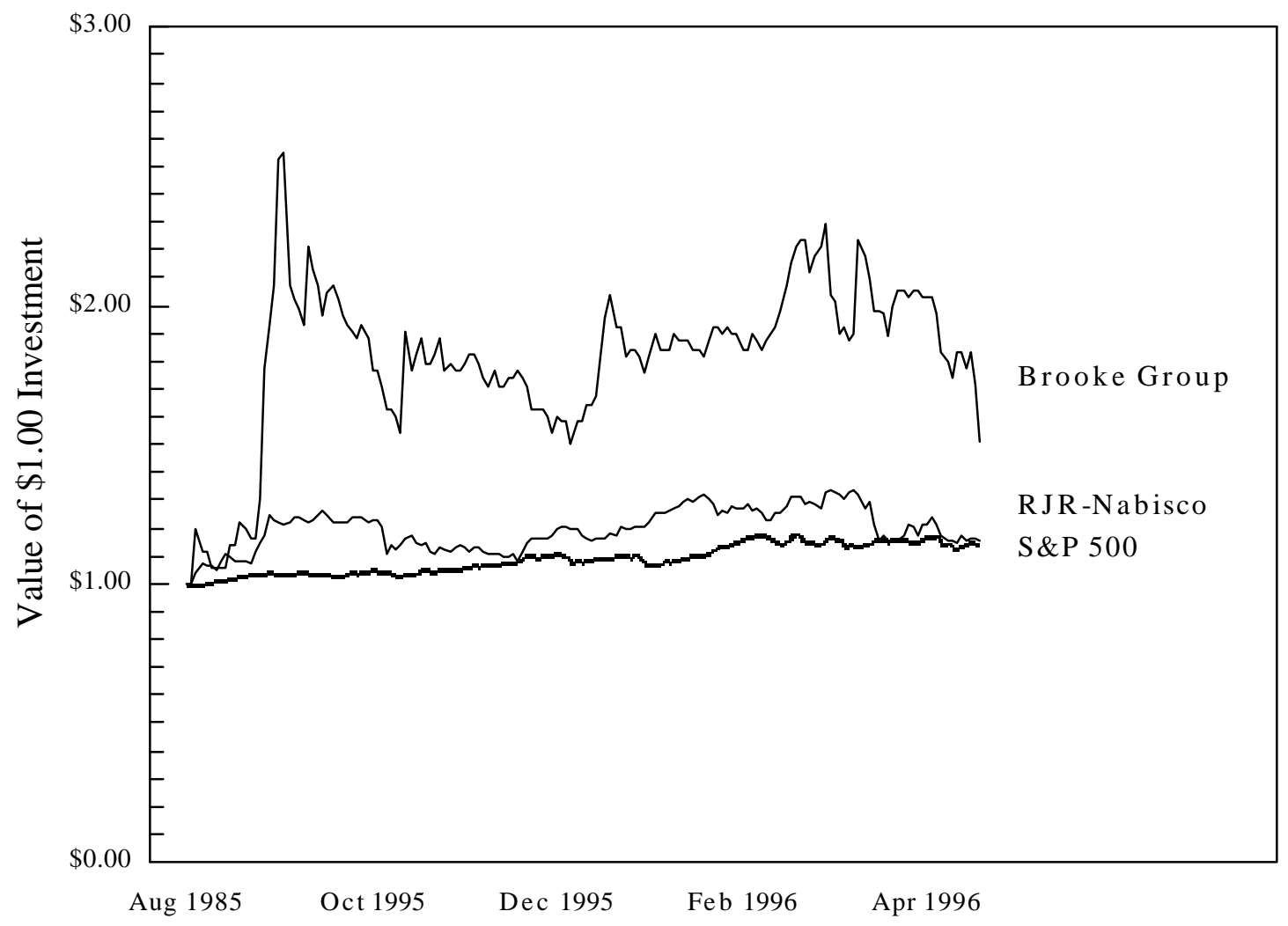




\section{Figure V}

\section{Tobacco Company Stock Returns After Liggett's 1996 Settlement}

Cumulative daily stock returns for the four U.S. tobacco manufacturers and the S\&P 500 Index around the time of Liggett's March 13, 1996, announcement of the settlement of the Castano class action tobacco litigation. Stock return information was obtained from the CRSP database.

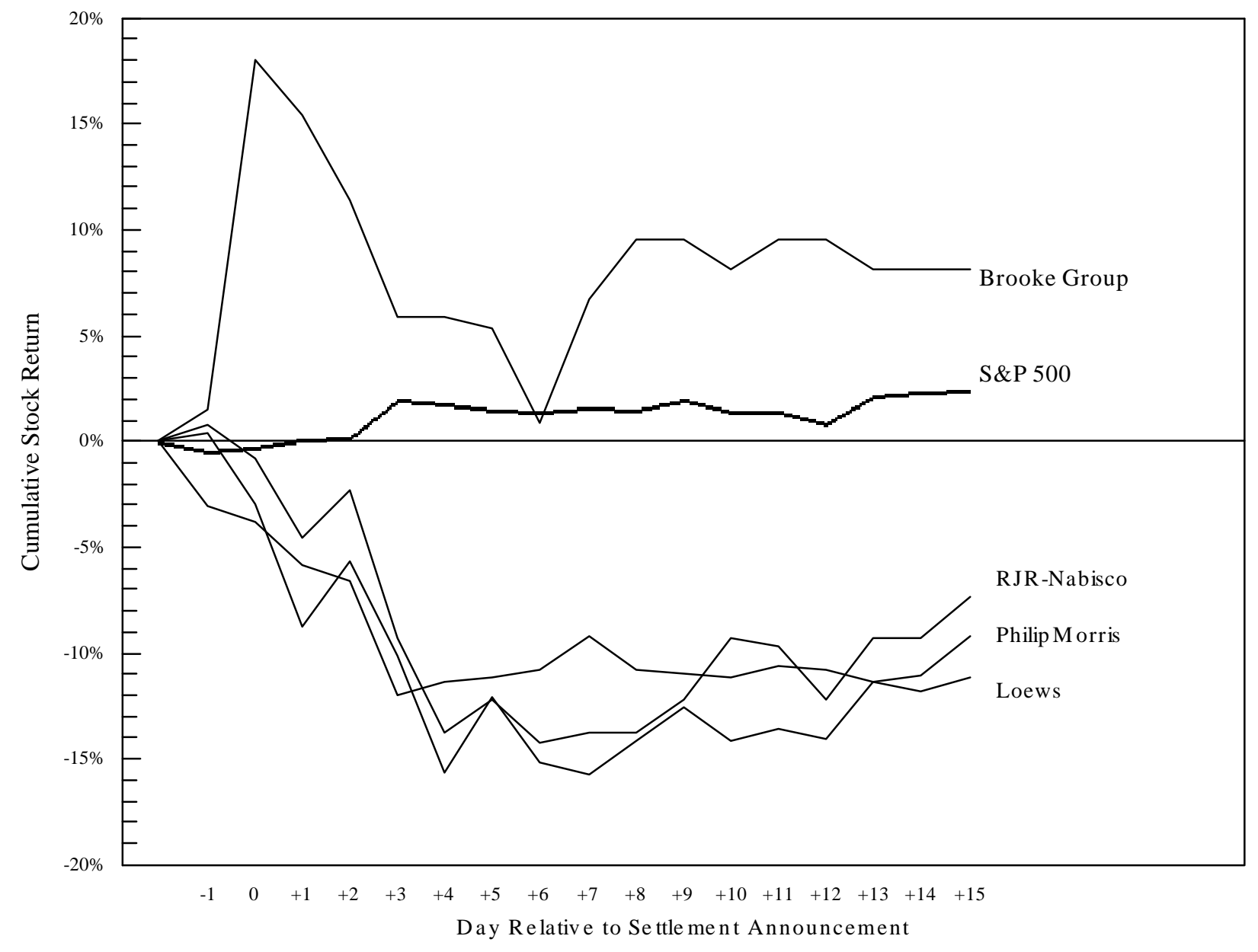




\section{Figure VI}

\section{Tobacco Company Stock Returns During Settlement Negotiation Period}

Value of a $\$ 1.00$ investment in the stocks of U.S. tobacco manufacturers compared to the S\&P 500 Index during the period in which the major tobacco companies attempted to negotiate a comprehensive settlement of litigation brought by state governments and individual plaintiffs. Stock return information was obtained from the CRSP database.

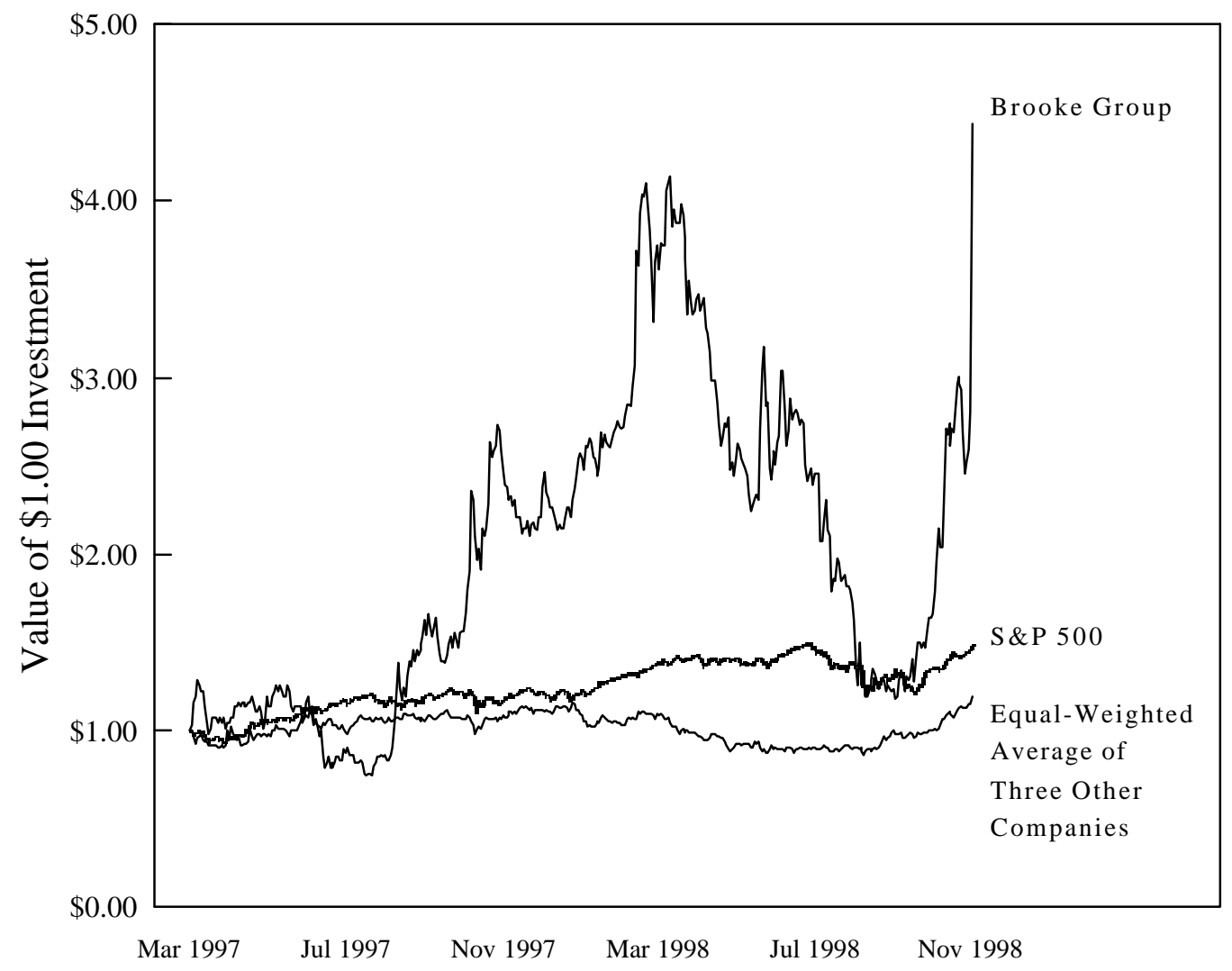




\section{Table 1}

\section{Major Investment Proposals by Bennett LeBow}

Major investment proposals by Bennett LeBow, whether successful or unsuccessful, apart from his involvement with Liggett. Information was obtained from news reports and company filings. In addition to those ventures listed, LeBow at various times owned interests in the jewelry, photostatic copying, shipbuilding, and real estate industries.

\begin{tabular}{|c|c|c|c|}
\hline Date & Firm & Transaction & Outcome \\
\hline 1967 & DSI Systems & $\begin{array}{l}\text { Company started by } \\
\text { LeBow }\end{array}$ & $\begin{array}{l}\text { Major restructuring in } \\
1969, \text { sold in } 1971\end{array}$ \\
\hline 1980 & $\begin{array}{l}\text { Information Displays } \\
\text { Inc. }\end{array}$ & $\begin{array}{l}\text { Majority equity } \\
\text { investment }\end{array}$ & $\begin{array}{l}\text { Sold in } 1984 \text {. Buyer files } \\
\text { Chapter } 11 \text {, sues LeBow }\end{array}$ \\
\hline 1985 & $\begin{array}{l}\text { ShowBiz Pizza Time } \\
\text { Inc. }\end{array}$ & $\begin{array}{l}\text { Purchases } 6.4 \text { percent } \\
\text { and launches proxy fight }\end{array}$ & Loses shareholder vote \\
\hline 1985 & $\begin{array}{l}\text { MAI Basic Four } \\
\text { Information Systems }\end{array}$ & $\begin{array}{l}\text { Acquired in } \$ 105 \text { million } \\
\text { LBO }\end{array}$ & Files Chapter 11 in 1993 \\
\hline 1986 & $\begin{array}{l}\text { Northwestern Steel and } \\
\text { Wire }\end{array}$ & $\begin{array}{l}\$ 165 \text { million acquisition } \\
\text { proposal }\end{array}$ & Rejected by shareholders \\
\hline 1986 & Brigham's & $\begin{array}{l}\text { Ice cream chain acquired } \\
\text { for } \$ 17 \text { million }\end{array}$ & Divested in 1991 \\
\hline 1987 & $\begin{array}{l}\text { Western Union Corp. } \\
\text { (renamed New Valley) }\end{array}$ & $\begin{array}{l}\text { LeBow acquires control } \\
\text { during restructuring }\end{array}$ & Files Chapter 11 in 1993 \\
\hline 1988 & Allegheny International & $\begin{array}{l}\text { Suggests alternative } \\
\text { reorganization plan }\end{array}$ & Rejected by shareholders \\
\hline 1988 & Prime Computer & $\$ 970$ million hostile bid & Rejected by management \\
\hline 1988 & American Brands & $\begin{array}{l}\text { Obtains regulatory } \\
\text { clearance for bid }\end{array}$ & Rejected by management \\
\hline 1989 & SkyBox International. & $\begin{array}{l}\text { Trading card business } \\
\text { started by Brooke Group }\end{array}$ & $\begin{array}{l}\text { Divested in } 1995 \\
\text { for } \$ 165 \text { million }\end{array}$ \\
\hline
\end{tabular}




\section{Table 2}

\section{Milestones in U.S. Regulation of Tobacco}

Major events involving research into health effects of smoking and U.S. government regulatory initiatives up to 1994, before negotiations began for a comprehensive settlement of litigation against the tobacco industry. Information was obtained from news sources including Dow Jones News-Retrieval and Lexis-Nexis.

\begin{tabular}{ll}
\hline Date & Event \\
\hline $1950-53$ & $\begin{array}{l}\text { Dr. Richard Doll, a British scientist, reports higher occurrence of lung cancer in } \\
\text { smokers. Sloan-Kettering Institute publishes report relating smoking to cancer. }\end{array}$ \\
1964 & U.S. Surgeon General's report on hazards of smoking. \\
1965 & $\begin{array}{l}\text { Federal Cigarette Labeling and Advertising Act requires health warnings on } \\
\text { cigarette packaging and advertising. }\end{array}$ \\
1970 & $\begin{array}{l}\text { Public Health Cigarette Smoking Act bans cigarette advertising on radio and } \\
\text { television. }\end{array}$ \\
1973 & $\begin{array}{l}\text { Civil Aeronautics Board orders separation of smokers and non-smokers on } \\
\text { flights. }\end{array}$ \\
1973 & Arizona becomes first state to ban smoking in public places. \\
1993 & Environmental Protection Agency declares second-hand smoke a carcinogen. \\
1994 & $\begin{array}{l}\text { CEOs of leading tobacco firms testify before Congress and are widely criticized } \\
\text { for claiming that smoking is not addictive. }\end{array}$
\end{tabular}




\section{Table 3}

\section{Financial Characteristics of Major U.S. Cigarette Manufacturers (1995 fiscal year)}

Descriptive statistics for the four U.S.-owned cigarette manufacturers in 1995. Financial data were obtained from the CRSP and Compustat databases. Share ownership data were obtained from company proxy statements, and product information was obtained from tobacco trade publications. The remaining market share was held by Brown \& Williamson and American Brands, two wholly-owned subsidiaries of the U.K. tobacco manufacturer B.A.T. Plc. All dollar amounts are in millions. EBDIT stands for earnings before depreciation, interest, and taxes, and total capital equals the market value of equity plus the book value of long-term debt.

\begin{tabular}{lrrrr}
\hline & $\begin{array}{r}\text { Brooke Group } \\
\text { (Liggett) }\end{array}$ & $\begin{array}{r}\text { Loews } \\
\text { (Lorillard) }\end{array}$ & $\begin{array}{r}\text { Philip } \\
\text { Morris }\end{array}$ & $\begin{array}{r}\text { RJR- } \\
\text { Nabisco }\end{array}$ \\
\hline Sales & $\$ 338$ & $\$ 17,239$ & $\$ 53,139$ & $\$ 16,008$ \\
EBDIT & $\$ 14$ & $\$ 2,364$ & $\$ 12.141$ & $\$ 3,610$ \\
EBDIT / sales & $4 \%$ & $14 \%$ & $23 \%$ & $23 \%$ \\
Market value of equity & $\$ 160$ & $\$ 4,623$ & $\$ 75,335$ & $\$ 8,283$ \\
Long-term debt & $\$ 407$ & $\$ 3,950$ & $\$ 13,107$ & $\$ 10,383$ \\
Long term debt / total capital & $72 \%$ & $46 \%$ & $15 \%$ & $56 \%$ \\
Largest shareholder & Bennett LeBow & Tisch family & Fidelity & $\begin{array}{r}\text { Fidelity } \\
\text { (\% holding) }\end{array}$ \\
Market Share & $(56.5 \%)$ & $(15.8 \%)$ & $(6.1 \%)$ & $(12.6 \%)$ \\
Leading Brands & $2 \%$ & $7 \%$ & $43 \%$ & $28 \%$ \\
& L\&M, & Newport, & Marlboro, & Winston, \\
& Chesterfield & Kent & Va. Slims & Camel \\
\hline
\end{tabular}




\section{Table 4}

\section{Major Events in LeBow's Battle for Control of RJR-Nabisco}

Major events and associated stock market reactions during Bennett LeBow's 1995-96 battle for control of RJR-Nabisco. The table presents three-day abnormal returns for the stock of both Brooke Group and RJR-Nabisco, measured in both percent change in stock price and increase in market capitalization (in millions). Abnormal returns are calculated as the difference between the stock price return and the return on the S\&P 500 Index. T-statistics appear in parentheses below abnormal market capitalization changes.

\begin{tabular}{|c|c|c|c|c|c|}
\hline \multicolumn{5}{|c|}{ Three-Day Abnormal Returns } & \multirow[b]{4}{*}{ Event } \\
\hline \multicolumn{2}{|c|}{ Brooke Group } & \multicolumn{2}{|c|}{ RJR-Nabisco } & \multirow[b]{3}{*}{ Date } & \\
\hline Excess & Market & Excess & Market & & \\
\hline Return & Cap. $\ddot{\mathrm{A}}$ & Return & Cap. $\ddot{A}$ & & \\
\hline $10.55 \%$ & $\begin{array}{r}\$ 9 \\
(1.36)\end{array}$ & $6.01 \%$ & $\begin{array}{r}\$ 438 \\
* *(2.06)\end{array}$ & $8 / 30 / 95$ & $\begin{array}{l}\text { LeBow receives antitrust clearance } \\
\text { to buy } 15 \text { percent of RJR-Nabisco; } \\
\text { RJR discloses rejection of proposal } \\
\text { to merge tobacco operations }\end{array}$ \\
\hline $58.75 \%$ & $\begin{array}{r}\$ 63 \\
* * *(7.58)\end{array}$ & $6.54 \%$ & $\begin{array}{r}\$ 542 \\
* *(2.25)\end{array}$ & $9 / 20 / 95$ & $\begin{array}{l}\text { Icahn seeks FTC approval to } \\
\text { acquire } 15 \text { percent of RJR }\end{array}$ \\
\hline $9.62 \%$ & $\begin{array}{r}\$ 13 \\
(1.24)\end{array}$ & $3.36 \%$ & $\begin{array}{r}\$ 272 \\
(1.15)\end{array}$ & $10 / 30 / 95$ & $\begin{array}{l}\text { LeBow and Icahn announce } 4.8 \\
\text { percent stake in RJR, ask RJR to } \\
\text { spin off food division }\end{array}$ \\
\hline $0.03 \%$ & $\begin{array}{r}\$ 0 \\
(0.00)\end{array}$ & $(3.53 \%)$ & $\begin{array}{r}(\$ 291) \\
(1.21)\end{array}$ & $11 / 2 / 95$ & $\begin{array}{l}\text { RJR management rejects proposal } \\
\text { for spinoff of food business }\end{array}$ \\
\hline$(6.83 \%)$ & $\begin{array}{r}(\$ 10) \\
(0.88)\end{array}$ & $4.26 \%$ & $\begin{array}{r}\$ 341 \\
(1.46)\end{array}$ & $12 / 6 / 95$ & RJR CEO Charles Harper resigns \\
\hline $8.77 \%$ & $\begin{array}{r}\$ 11 \\
(1.13)\end{array}$ & $(3.39 \%)$ & $\begin{array}{r}(\$ 288) \\
(1.16)\end{array}$ & $12 / 20 / 95$ & $\begin{array}{l}\text { New RJR CEO Steven Goldstone } \\
\text { reiterates objections to spinoff }\end{array}$ \\
\hline $9.92 \%$ & $\begin{array}{r}\$ 15 \\
(1.28)\end{array}$ & $2.85 \%$ & $\begin{array}{r}\$ 255 \\
(0.98)\end{array}$ & $2 / 21 / 96$ & $\begin{array}{l}\text { LeBow and Icahn win proxy battle } \\
\text { with } 50.4 \text { percent; management still } \\
\text { refuses spinoff; LeBow and Icahn } \\
\text { launch proxy fight for board }\end{array}$ \\
\hline $16.51 \%$ & $\begin{array}{r}\$ 25 \\
* *(2.13)\end{array}$ & $(4.62 \%)$ & $\begin{array}{r}(\$ 435) \\
(1.58)\end{array}$ & $3 / 13 / 96$ & $\begin{array}{l}\text { LeBow announces settlement of } \\
\text { Castano class action litigation }\end{array}$ \\
\hline
\end{tabular}




\begin{tabular}{rrrrrl}
$(8.47 \%)$ & $(\$ 13)$ & $(1.04 \%)$ & $\begin{array}{r}(\$ 89) \\
(1.09)\end{array}$ & $04 / 09 / 96$ & $\begin{array}{l}\text { Institutional Shareholder Services } \\
\text { recommends voting against LeBow } \\
\text { and Icahn due to settlement }\end{array}$ \\
$(14.67 \%)$ & $\begin{array}{r}(\$ 21) \\
*(1.89)\end{array}$ & $0.25 \%$ & $\begin{array}{r}\$ 20 \\
(0.08)\end{array}$ & $04 / 17 / 96$ & $\begin{array}{l}\text { LeBow concedes defeat in proxy } \\
\text { vote }\end{array}$ \\
$\mathbf{3 1 . 7 6 \%}$ & $\begin{array}{r}\mathbf{\$ 2 6} \\
(\mathbf{0 . 5 6})\end{array}$ & $\mathbf{0 . 6 0 \%}$ & $\begin{array}{r}\mathbf{\$ 4 4} \\
\mathbf{( 0 . 0 3 )}\end{array}$ & Entire Period \\
\hline
\end{tabular}

Significant at 1 percent $(* * *), 5$ percent $(* *)$, and 10 percent $(*)$ levels, respectively. 


\section{Table 5}

\section{Major Events in Tobacco Settlement Negotiations}

Major events and associated stock market reactions during the period in which the major tobacco companies attempted to negotiate a comprehensive settlement of litigation brought by state governments and individual plaintiffs. The table presents three-day abnormal returns for the stock of Brooke Group and an equal-weighted average of the stocks of Philip Morris, RJR-Nabisco, and Loews, as well as abnormal market capitalization changes for Brooke Group and for the sum total of the three other tobacco companies. Abnormal returns are calculated as the difference between the stock price return and the return on the S\&P 500 Index. T-statistics appear in parentheses below abnormal market capitalization changes.

\begin{tabular}{rrrrrl}
\hline \multicolumn{6}{c}{ Three-Day Abnormal Returns } \\
\hline \multicolumn{5}{c}{ Other Tobacco } \\
Crompanies
\end{tabular}




\begin{tabular}{|c|c|c|c|c|c|}
\hline$(11.80 \%)$ & $\begin{array}{r}(\$ 19) \\
(1.52)\end{array}$ & $1.94 \%$ & $\begin{array}{r}\$ 2,931 \\
*(1.76)\end{array}$ & $6 / 18 / 98$ & $\begin{array}{l}\text { Senate votes to delay further action } \\
\text { on McCain bill }\end{array}$ \\
\hline$(3.00 \%)$ & $\begin{array}{r}(\$ 2) \\
(0.39)\end{array}$ & $3.52 \%$ & $\begin{array}{r}\$ 2,118 \\
(1.09)\end{array}$ & $8 / 26 / 98$ & $\begin{array}{l}\text { Negotiations reopen between states } \\
\text { and companies }\end{array}$ \\
\hline $70.02 \%$ & $\begin{array}{r}\$ 96 \\
* * *(9.03)\end{array}$ & $2.03 \%$ & $\begin{array}{r}\$ 2,755 \\
(1.19)\end{array}$ & $11 / 20 / 98$ & $\begin{array}{l}\text { Settlement with } 46 \text { states announced; } \\
\text { Brooke Group receives } \$ 300 \text { million } \\
\text { from Philip Morris for three brands }\end{array}$ \\
\hline $195.24 \%$ & $\begin{array}{r}\$ 154 \\
* *(2.11)\end{array}$ & $(20.38 \%)$ & $\begin{array}{r}(\$ 7,611) \\
(0.25)\end{array}$ & & Entire Period \\
\hline
\end{tabular}

Significant at 1 percent $(* * *), 5$ percent $(* *)$, and 10 percent $(*)$ levels, respectively. 